Resectron

\title{
A central role for the mammalian target of rapamycin in LPS-induced anorexia in mice
}

\author{
Yunshuang Yue, Yi Wang, Dan Li, Zhigang Song, Hongchao Jiao and Hai Lin \\ Shandong Key Lab for Animal Biotechnology and Disease Control, Department of Animal Science, Shandong \\ Agricultural University, No. 61, Daizong Street, Taian, Shandong 271018, People's Republic of China
}

Correspondence should be addressed to $\mathrm{H}$ Lin

Email

hailin@sdau.edu.cn

\begin{abstract}
Bacterial lipopolysaccharide (LPS), also known as endotoxin, induces profound anorexia.

However, the LPS-provoked pro-inflammatory signaling cascades and the neural mechanisms

underlying the development of anorexia are not clear. Mammalian target of rapamycin

(mTOR) is a key regulator of metabolism, cell growth, and protein synthesis. This study aimed

to determine whether the mTOR pathway is involved in LPS-induced anorexia. Effects of LPS on hypothalamic gene/protein expression in mice were measured by RT-PCR or western blotting analysis. To determine whether inhibition of mTOR signaling could attenuate LPS-induced anorexia, we administered an i.c.v. injection of rapamycin, an mTOR inhibitor, on LPS-treated male mice. In this study, we showed that LPS stimulates the mTOR signaling pathway through the enhanced phosphorylation of $\mathrm{mTOR}^{\mathrm{Ser} 2448}$ and $\mathrm{p70S6 \textrm {K } ^ { \mathrm { Th } } 3 8 9}$. We also showed that LPS administration increased the phosphorylation of FOXO1 ${ }^{\text {Ser256, the }}$ p65 subunit of nuclear factor kappa $B(P<0.05)$, and FOXO1/3a $a^{\text {Thr24/32 }}(P<0.01)$. Blocking the mTOR pathway significantly attenuated the LPS-induced anorexia by decreasing the phosphorylation of $\mathrm{p} 70 \mathrm{~S} 6 \mathrm{~K}^{\mathrm{Thr} 389}$, FOXO1 $1^{\mathrm{Ser} 256}$, and FOXO1/3a $\mathrm{T}^{\text {Thr24/32 }}$. These results suggest promising approaches for the prevention and treatment of LPS-induced anorexia.
\end{abstract}

Key Words

- anorexia

- FoxO1

- hypothalamus

\section{Introduction}

Overwhelming evidence has suggested that infectious and non-infectious pathogens stimulate the production of proinflammatory cytokines and induce weight loss and anorexia (Socher et al. 1988, Tracey et al. 1988, Grunfeld et al. 1989). Transcription factor nuclear factor kappa B $(\mathrm{NF} \kappa \mathrm{B})$ is a key regulator of genes encoding cytokines, cytokine receptors, and cell adhesion molecules that stimulate inflammatory responses (Hayden \& Ghosh 2008). Peripherally, lipopolysaccharide (LPS) activates $\mathrm{NF} \kappa \mathrm{B}$, which results in the production of proinflammatory cytokines, such as interleukin 1 (IL1), tumor necrosis factor alpha (TNF $\alpha$ ), and IL6 (Johnson 1997,
Segreti et al. 1997, Finck et al. 1998). NFкB normally remains inactive in the cytoplasm, as it is bound to $\mathrm{I} \kappa \mathrm{B} \alpha$, and translocates into the nucleus in response to LPS stimulation (Li \& Karin 1999). In addition, LPS modulates

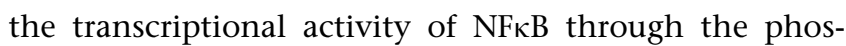
phorylation of the NFКB p65 subunit (Kim et al. 2011). It has been reported that cytokines have direct action on the central response to inflammatory stimuli, especially LPS (Laye et al. 2000, Sergeyev et al. 2001, Ogimoto et al. 2006). In the hypothalamus, however, the mechanisms by which NFKB integrates the LPS signals to regulate food intake remain unclear.

Published by Bioscientifica Ltd. 
The mammalian target of rapamycin (mTOR), an evolutionarily conserved serine/threonine kinase, regulates critical aspects of the regulation of cell growth, including transcription, translation initiation and elongation, and cell cycle progression, by responding to changes in energy status (Wullschleger et al. 2006). In addition, mTOR is necessary to control food intake by integrating the signals that monitor the nutritional and hormonal signals in the hypothalamus (Cota et al. 2006, Ropelle et al. 2008a,b). An active hypothalamic mTOR signaling pathway suppresses food intake; however, hypothalamic mTOR inhibition by i.c.v. injection of rapamycin significantly increased the short-term food intake in pre-satiated rats (Cota et al. 2006). mTOR is downstream of the phosphatidyl inositol 3-kinase (PI3K)/AKT pathways; therefore, both insulin- and leptininduced anorectic effects can be blocked by the inhibition of PI3K (Niswender et al. 2001, 2003). Cota et al. (2006) observed that the inactivation of mTOR with rapamycin apparently attenuated the anorexia and body weight loss induced by leptin.

Importantly, recent studies have indicated that the serine/threonine kinase AKT regulated the activation of $\mathrm{NF \kappa B}$ following exposure to LPS in human macrophages (Monick et al. 2001). This finding suggests that the mTOR signaling pathway plays an important role in the activation of NFKB in immune cells. However, whether the mTOR pathway is involved in the activation of NFкB in the hypothalamus remains unknown.

The forkhead transcriptional factor subfamily forkhead box O1 (FoxO1) is another important downstream target of the PI3K/AKT pathways (Tang et al. 1999). Activated AKT phosphorylates FOXO1, leading to its nuclear exclusion and proteasomal degradation (Matsuzaki et al. 2003, Aoki et al. 2004). FOXO1 is a shared component that regulates peripheral metabolism and food intake (Kim et al. 2006). Previous studies have shown that FOXO1 protein plays essential roles in the transcriptional cascades that are responsible for metabolism in the muscle, liver, brain, pancreas, and adipose tissues (Nakae et al. 2002, Kamei et al. 2004, Kim et al. 2006, 2009). In the CNS, leptin decreases the expression of FOXO1 in the hypothalamus and induces a reduction in food intake and body weight (Kim et al. 2006, Kitamura et al. 2006). Activation of FOXO1 promotes coactivator-corepressor exchange and, therefore, activates agouti-related peptide (AGRP) expression and inhibits pro-opiomelanocortin (POMC) expression (Accili \& Arden 2004). Therefore, it is important to understand how these pathways in the hypothalamus respond to LPS-induced anorexia.
We hypothesized that the mTOR pathway is involved in LPS-induced anorexia. In this study, the interactions between the inflammatory signals induced by LPS and the neuronal regulatory network related to appetite control were investigated during the development of anorexia. The results indicated that the mTOR signaling pathway is involved in LPS-induced anorexia, and the inhibition of mTOR signaling provides an attractive way to alleviate LPS-induced anorexia.

\section{Materials and methods}

\section{Animals}

Kunming male mice (7-10 weeks old) were housed in a controlled environment of $24^{\circ} \mathrm{C}$ with a $12 \mathrm{~h}$ light: $12 \mathrm{~h}$ darkness cycle. All mice were fed in individual cages and had free access to standard chow and water before the experiments started. The experimental procedures were approved by the Institutional Animal Care and Use Committees in accordance with the criteria outlined in the Guide for the Care and Use of Laboratory Animals (Beijing, People's Republic of China).

\section{Food intake and body weight measurements after LPS injection}

Mice were randomly divided into four groups, with six mice in each group, and all mice were fasted for $24 \mathrm{~h}$ before the experiment. At the start of the dark cycle, the mice were injected intraperitoneally with LPS (Escherichia coli $055: B 5$, Sigma) at dosages of $0,10,100$, or $1000 \mu \mathrm{g} / \mathrm{kg}$ $\mathrm{BW}$ and were then given immediate access to food. Food intake was recorded after 1, 2, 4, 6, 8, 12, 18, and $24 \mathrm{~h}$. Body weight was recorded at $0,24,48$, and $72 \mathrm{~h}$ after injection. Time course was used to determine the response to LPS treatment.

\section{Implantation of i.c.v. cannulae}

After an overnight fast, the mice were anesthetized by i.p. injection of 3\% pentobarbital sodium (Merck) at a dose of $40 \mathrm{mg} / \mathrm{kg}$ body weight. The mice were mounted using a stereotaxic apparatus (Huai Bei Zheng Hua, Anhui, China), and a small incision was made in the flesh along the midline. The cannula was fixed to the skull with dental cement. The coordinates of the third cerebral ventricle from the bregma was $1.82 \mathrm{~mm}$ posterior to the bregma and $5 \mathrm{~mm}$ below the surface of the skull. The mice were allowed to recover for 1 week before the experiment.

Published by Bioscientifica Ltd. 


\section{I.c.v. injection}

After a 24-h fast, four groups of mice were subjected to two treatments: i.c.v. injected with rapamycin (R0395-1MG, Sigma) or the vehicle (DMSO in artificial cerebrospinal fluid) $2 \mathrm{~h}$ before the start of the dark cycle (Cota et al. 2006, Verhulst et al. 2012); rapamycin was dissolved in DMSO at a concentration of $25 \mathrm{mg} / \mathrm{ml}$ and was used at a final concentration of $20 \mu \mathrm{g} / 2 \mu \mathrm{l}$. Following the infusion, the guide cannula remained inserted for $\sim 30$ s to allow the drug to diffuse away from the cannula tip. One hour later, the two groups of mice in each treatment were given an i.p. injection of either $500 \mu \mathrm{g} / \mathrm{kg}$ LPS or saline. The mice were then returned to their cages, and food was returned $2 \mathrm{~h}$ later. The cumulative food intake was recorded at 1,2 , 4,6 , and $12 \mathrm{~h}$ from food reoffered.

\section{Nuclear and cytoplasmic protein extract}

Twelve mice were randomly divided into two groups $(n=6$ in each group) and were fasted for $20 \mathrm{~h}$ prior to the experiment. At the start of the dark cycle, the mice were injected intraperitoneally with $500 \mu \mathrm{g} / \mathrm{kg}$ (BW) LPS or saline. Two hours later, the mice were killed by decapitation, and the hypothalami were promptly removed according to Kim et al. (2004) to extract the nuclear and cytoplasmic proteins. The nuclear and cytoplasmic protein extractions were conducted on ice with the Nuclear and Cytoplasmic Protein Extraction Kit (Beyotime, Jiangsu, People's Republic of China) according to the manufacturer's instructions. Proteins were then stored at $-80{ }^{\circ} \mathrm{C}$ until further analysis.

\section{Gene expression analysis}

According to the effects of LPS administration on food intake and body weight, the 100 or/and $500 \mu \mathrm{g} / \mathrm{kg}$ BW doses of LPS were chosen for the subsequent experiments. The mice were fasted for $24 \mathrm{~h}$ and received pretreatment with rapamycin or vehicle; the mice were then injected intraperitoneally with $500 \mu \mathrm{g} / \mathrm{kg}$ (BW) LPS or saline. Two hours later, the mice were killed and the hypothalami were promptly removed. The samples were rapidly frozen in liquid nitrogen and then stored at $-80^{\circ} \mathrm{C}$ until further analysis.

Total RNA was isolated from the hypothalami using TRIzol reagent (Invitrogen). The integrity and concentration of the RNA were assessed by measuring the optical density at 260-280 nm using a biophotometer (Eppendorf, Hamburg, Germany). Total RNA ( $1 \mu \mathrm{g})$ was reverse transcribed using the PrimeScript RT Reagent Kit (Perfect Real Time, TaKaRa, Dalian, China) according to the manufacturer's procedures. Quantitative real-time RT-PCR (qRT-PCR) was conducted using SYBR Green I Dye (TaKaRa) on an Applied Biosystems Real-time PCR System 7500 (Applied Biosystems). The qRT-PCR included a $95^{\circ} \mathrm{C}$ denaturation step for $10 \mathrm{~s}$ followed by 40 cycles of $95^{\circ} \mathrm{C}$ for $5 \mathrm{~s}$ and $60{ }^{\circ} \mathrm{C}$ for $40 \mathrm{~s}$. The primer sequences used in the qRT-PCR analysis are listed in Table 1. The housekeeping gene used for correction was $\beta$-actin. Relative mRNA abundance was calculated according to the established method (Livak \& Schmittgen 2001).

Table 1 Gene-specific primers used for the analysis of gene expression

\begin{tabular}{|c|c|c|c|}
\hline Gene & GenBank accession no. & Primer sequences $\left(5^{\prime}-3^{\prime}\right)$ & Product size (bp) \\
\hline$\beta$-actin & NM_007393.3 & $\begin{array}{l}\text { F: ACCACACCTTCTACAATGAG } \\
\text { R: ACGACCAGAGGCATACAG }\end{array}$ & 182 \\
\hline POMC & NM_008895.3 & $\begin{array}{l}\text { F: CGGGAGGCGACGGAAGAGAAAA } \\
\text { R: AACAAGATTGGAGGGACCCCTGT }\end{array}$ & 112 \\
\hline$N P Y$ & NM_023456.2 & $\begin{array}{l}\text { F: CCGCCACGATGCTAGGTAACAAG } \\
\text { R: CCCTCAGCCAGAATGCCCAAAC }\end{array}$ & 91 \\
\hline$A G R P$ & NM_007427.2 & $\begin{array}{l}\text { F: GCGGAGGTGCTAGATCCACAGAA } \\
\text { R: AAGGCATTGAAGAAGCGGCAGTAG }\end{array}$ & 137 \\
\hline$T N F \alpha$ & NM_013693.2 & $\begin{array}{l}\text { F: AAGCCTGTAGCCCACGTCGTA } \\
\text { R: GGCACCACTAGTTGGTTGTCTTTG }\end{array}$ & 122 \\
\hline IL6 & NM_031168.1 & $\begin{array}{l}\text { F: GAGGATACCACTCCCAACAGACC } \\
\text { R: AAGTGCATCATCGTTGTTCATACA }\end{array}$ & 141 \\
\hline$I L 1 \alpha$ & NM_010554.4 & $\begin{array}{l}\text { F: TCGGGAGGAGACGACTCTAA } \\
\text { R: AGGTCGGTCTCACTACCTGTG }\end{array}$ & 146 \\
\hline$I L 1 \beta$ & NM_008361.3 & $\begin{array}{l}\text { F: GAAGAAGAGCCCATCCTCTG } \\
\text { R: TCATCTCGGAGCCTGTAGTG }\end{array}$ & 98 \\
\hline
\end{tabular}

POMC, pro-opiomelanocortin; NPY, neuropeptide Y; AgRP, agouti-related peptide; TNF $\alpha$, tumor necrosis factor alpha; IL6, interleukin 6; IL1 $\alpha$, interleukin 1 alpha; IL1 $\beta$, interleukin 1 beta.

http://joe.endocrinology-journals.org DOI: 10.1530/JOE-14-0523
(C) 2015 Society for Endocrinology Printed in Great Britain
Published by Bioscientifica Ltd 


\section{Western blotting analysis}

The mice were fasted for $24 \mathrm{~h}$ and received pretreatment with rapamycin; the mice were then injected intraperitoneally with $500 \mu \mathrm{g} / \mathrm{kg}$ (BW) LPS or saline. Two hours later, the mice were killed by decapitation and the hypothalami were quickly removed. The samples were rapidly frozen in liquid nitrogen and then stored at $-80^{\circ} \mathrm{C}$ until further analysis. Total protein was extracted from the hypothalami, which were lysed and homogenized in $500 \mu$ l of precooled Radio Immunoprecipitation Assay buffer (Beyotime) containing $50 \mathrm{mM}$ Tris (pH 7.4), $150 \mathrm{mM} \mathrm{NaCl}, 1 \% \mathrm{NP}-40,0.25 \%$ sodium deoxycholate, sodium orthovanadate, sodium fluoride, EDTA, and leupeptin and was supplemented with PhosStop Phosphatase Inhibitor (Roche) and $1 \mathrm{mM}$ phenylmethanesulfonyl fluoride (Beyotime). Then, the samples were centrifuged at $15294 \mathrm{~g}$ for $5 \mathrm{~min}$ at $4{ }^{\circ} \mathrm{C}$. The protein concentration was measured using the BCA Protein Assay Kit (Beyotime). The protein lysates were denatured for $10 \mathrm{~min}$ at $100^{\circ} \mathrm{C}$ and were then electrophoresed in running buffer on a $7.5-12 \%$ Trisglycine SDS-polyacrylamide gel. The lysates were transferred to a PVDF microporous membrane (Millipore, Billerica, MA, USA) at $80 \mathrm{~V}$ at $4{ }^{\circ} \mathrm{C}$ for $2 \mathrm{~h}$. After incubation for $1 \mathrm{~h}$ in block solution (5\% BSA, $0.1 \%$ Tween-20, and $0.02 \%$ sodium azide in PBS, $\mathrm{pH}$ 7.6) at room temperature, the membranes were incubated at $4{ }^{\circ} \mathrm{C}$ overnight in primary antibodies against phospho-p70S6 kinase (Thr389) (\#9234, Cell Signaling Technology, Inc., Beverly, MA, USA), phospho-FOXO1 (Ser256) (\#9461, Cell Signaling Technology, Inc.), phosphoFOXO1 (Thr24)/FOXO3a (Thr32) (\#9464, Cell Signaling Technology, Inc.), phospho-NFкB p65 (Ser536) (93H1) rabbit mAb (\#3033, Cell Signaling Technology, Inc.), phosphomTOR (Ser2448) (\#2971, Cell Signaling Technology, Inc.), p70S6 kinase (\#2708, Cell Signaling Technology, Inc.), mTOR (\#2983, Cell Signaling Technology, Inc.), FOXO1 (L27) (\#9454, Cell Signaling Technology, Inc.), NFкB p65 (C22B4) rabbit mAb (\#4764, Cell Signaling Technology, Inc.), and $\beta$-actin mouse monoclonal (AA128, Beyotime) respectively. The blots were then incubated with anti-rabbit or anti-mouse HRP-conjugated IgG (Bio-Rad Laboratories) for $1 \mathrm{~h}$. The bands were detected using Super Signal West Femto Maximum Sensitivity Substrate (Thermo Scientific, Pittsburgh, PA, USA) and were visualized by exposure to X-ray film (Kodak). Quantification was made using the Image J 1.43 Software (National Institutes of Health, Bethesda, MD, USA).

\section{Statistical analyses}

All data were analyzed with the SAS Software (SAS, version 8e; SAS Institute, Cary, NC, USA). A one-way ANOVA model was used to evaluate the means of the LPS treatment. Then, Duncan's multiple comparisons test was used to detect significant differences among the different groups. A two-way ANOVA was performed to evaluate the main effect of LPS administration and rapamycin treatment and their interaction. If a significant interaction was detected, differences among various groups were assessed with Duncan's multiple comparisons test. The data are shown as the mean \pm s.E.M. $P<0.05$ was regarded as statistically significant.

\section{Results}

\section{Effects of LPS on food intake and body weight}

Consistent with previous studies, we found that LPS treatment of $10-1000 \mu \mathrm{g} / \mathrm{kg}$ BW induced a significant decrease in food intake $(P<0.01$, Fig. 1$)$, with progressive bodyweight loss over the first $24 \mathrm{~h}$ (data not shown).

\section{Effect of LPS on the mTOR pathway}

To investigate whether mTOR signaling is associated with LPS-induced anorexia, we conducted western blotting analysis on the hypothalami of mice to evaluate the phosphorylation levels of mTOR and p70S6K. We determined the phosphorylation level of p70S6K at Thr389 at different time points after LPS treatment $(500 \mu \mathrm{g} / \mathrm{kg} \mathrm{BW})$. The results showed that the phosphorylation level of hypothalamic p70S6K was promoted after LPS administration $(P<0.05$, Fig. $2 \mathrm{~A})$. We then measured the phosphorylation levels of mTOR and p70S6K $2 \mathrm{~h}$ after LPS treatment $(500 \mu \mathrm{g} / \mathrm{kg}$ BW), and the results showed that phosphorylation levels of mTOR and p70S6K were significantly upregulated by LPS $(P<0.01$, Fig. 2B and C).

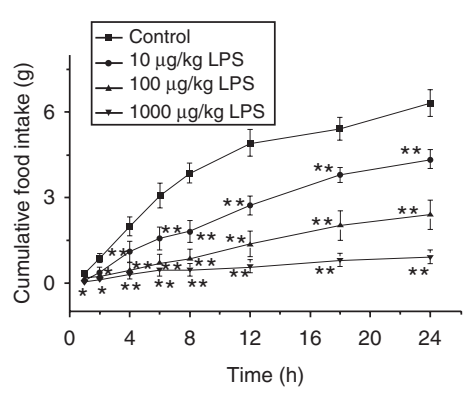

Figure 1

Effect of LPS treatment on food intake. The daily food intake was measured in the mice i.p. injected with LPS at doses of $0,10,100$, or $1000 \mu \mathrm{g} / \mathrm{kg}(\mathrm{BW})$. Values are the means \pm S.E.M. $\left(n=6\right.$ per group, ${ }^{*} P<0.05$ and $\left.* * P<0.01\right)$.

Published by Bioscientifica Ltd 

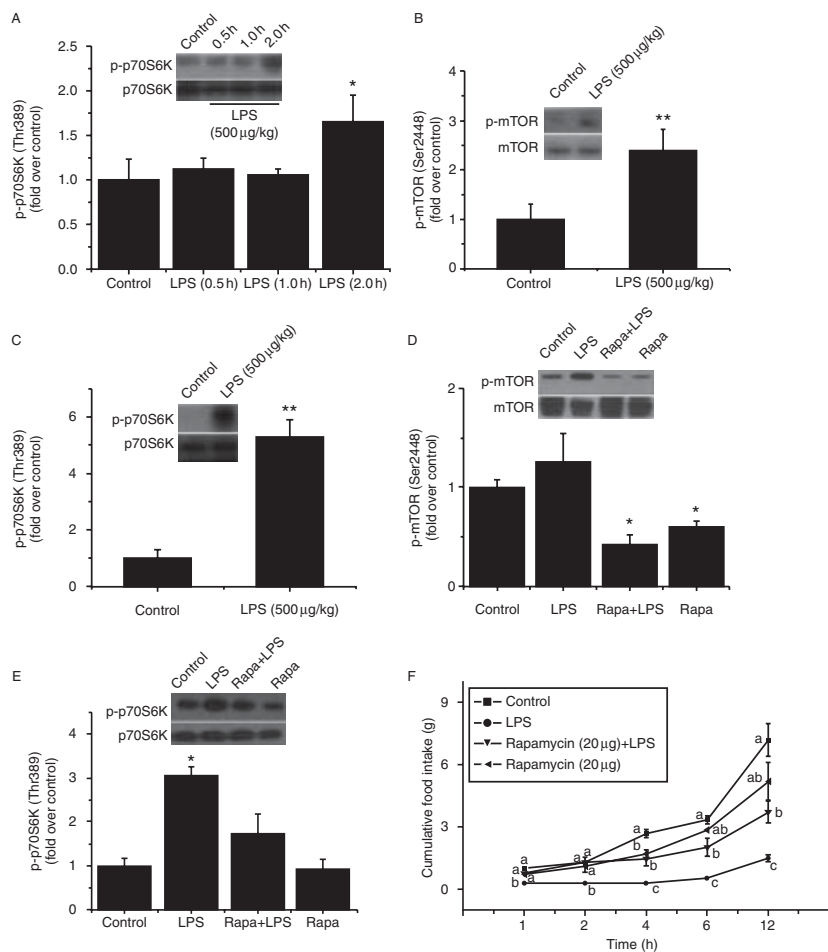

Figure 2

The mTOR plays a key role in LPS-induced anorexia. The phosphorylation of hypothalamic p7056K (A) was determined at various time points after LPS $(500 \mu \mathrm{g} / \mathrm{kg} \mathrm{BW})$ treatment. The levels of phospho-mTOR (Ser2448) (B) and phospho-p70S6 kinase (Thr389) (C) were determined in the hypothalami of mice $2 \mathrm{~h}$ after LPS $(500 \mu \mathrm{g} / \mathrm{kg})$ administration compared with the control (saline). Fasted mice were i.c.v. administered rapamycin (Rapa) or an equal volume of vehicle. One hour later, half of the mice were i.p. administered LPS (LPS and Rapa + LPS respectively). All measurements were determined $2 \mathrm{~h}$ after LPS treatment. (D) The level of hypothalamic phospho-mTOR (Ser2448). Two-way ANOVA showed a significant interaction between LPS and rapamycin treatment $(P<0.05)$. (E) The level of hypothalamic phosphop70S6K (Thr389). Two-way ANOVA showed a significant interaction between LPS and rapamycin treatment $(P<0.05)$. (F) Cumulative food intake (g). Two-way ANOVA showed a significant interaction between LPS and rapamycin treatment at all time points $(P<0.05)$; rapamycin was dissolved in DMSO at a concentration of $25 \mathrm{mg} / \mathrm{ml}$ and was used at a final concentration of $20 \mu \mathrm{g} / 2 \mu \mathrm{l}$. The values are the means \pm s.E.M. $(n=6$ mice per group). ${ }^{*} P<0.05$ and $* * P<0.01$, means without a common letter are different.

Rapamycin was used to investigate the effect of mTOR inhibition on the LPS-induced anorexia. The mice were pretreated with rapamycin $(20 \mu \mathrm{g} / 2 \mu \mathrm{l})$ for $1 \mathrm{~h}$, followed by i.p. injection of $500 \mu \mathrm{g} / \mathrm{kg}$ BW LPS. Inactivation of the mTOR pathway significantly decreased the LPS-induced phosphorylation of mTOR and p70S6K $\left(P_{\text {Rapa }}<0.05\right.$, Fig. 2D and E). As shown in Fig. 2F, mTOR inhibition significantly increased food intake in the mice challenged with LPS, and at $2 \mathrm{~h}$, the cumulative food intake was stimulated by $\sim 4$.3-fold compared with the consumption induced by a single injection of LPS $\left(P_{\text {Rapa } \times \text { LPS }}<0.05\right)$.

\section{Effects of LPS and mTOR inhibition on Ser536 phosphorylation of NFKB p65 and cytokine expression}

The levels of the pro-inflammatory cytokine and appetite gene expression were determined in the $500 \mu \mathrm{g} / \mathrm{kg}$ BW LPS administration group. The results showed that the mRNA levels of $I l 1 \alpha, I l 1 \beta, I l 6$, and Tnf $\alpha$ were significantly increased compared with the control group $(P<0.05$, Fig. 3C). The expression of the orexigenic appetite genes neuropeptide $\mathrm{Y}$ (Npy) showed no significant difference compared with the control group $(P>0.05$, Fig. 4I). In contrast, the expression of Pomc was significantly upregulated following LPS injection relative to the control $(P<0.05$, Fig. $4 \mathrm{I})$. We further detected the activation of $\mathrm{NF} \kappa \mathrm{B}$ and the results showed that the phosphorylation of the NFKB p65 subunit on Ser536 was elevated $\sim 1$.2-fold following LPS administration $(P<0.05$, Fig. $3 \mathrm{~A})$. The level of hypothalamic NFKB protein was significantly increased in the nuclear extracts $(P<0.05$, Fig. 3B). In addition, as shown in Fig. 3C, after mTOR inactivation, the expression of the proinflammatory cytokines $T n f \alpha$ and $I l 1 \alpha$, which were induced by LPS, were significantly reduced $\left(P_{\text {Rapa } \times \text { LPS }}<0.05\right)$, and the expression level of $I l 1 \beta$ exhibited a downward trend $\left(P_{\text {Rapa }}=0.05\right)$. However, the mRNA level of Il6 showed
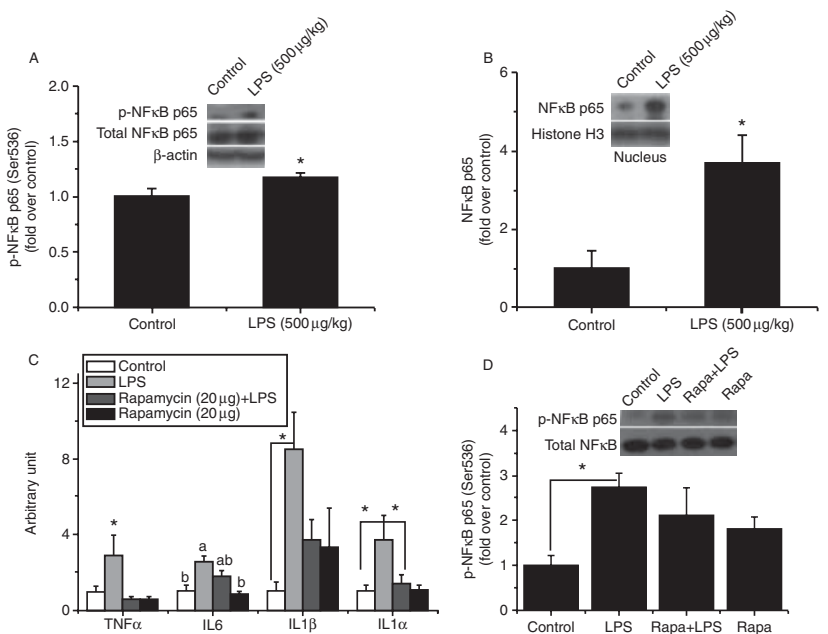

Figure 3

Cross talk of the mTOR and NFKB in LPS-induced anorexia. Effects of LPS $(500 \mu \mathrm{g} / \mathrm{kg})$ administration on the phosphorylation of hypothalamic NFKB p65 at Ser536 (A) and hypothalamic NFKB (p65) nuclear accumulation compared with the control (B). Fasted mice were i.c.v. administered rapamycin (Rapa) or an equal volume of vehicle. One hour later, half of the mice were i.p. administered LPS (LPS and Rapa + LPS respectively). All measurements were determined $2 \mathrm{~h}$ after LPS treatment. (C) The mRNA expression of pro-inflammatory cytokines in the hypothalami of mice. (D) The level of hypothalamic phospho-NFkB p65 (Ser536). The values are the means \pm S.E.M. ( $n=6$ mice per group). Means without a common letter differ significantly $(* P<0.05)$.

Published by Bioscientifica Ltd. 
A

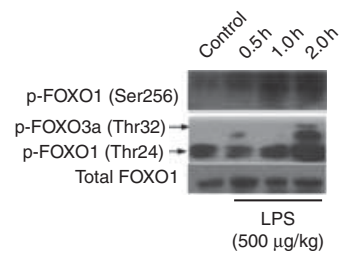

C

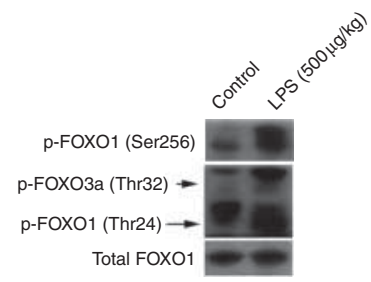

E
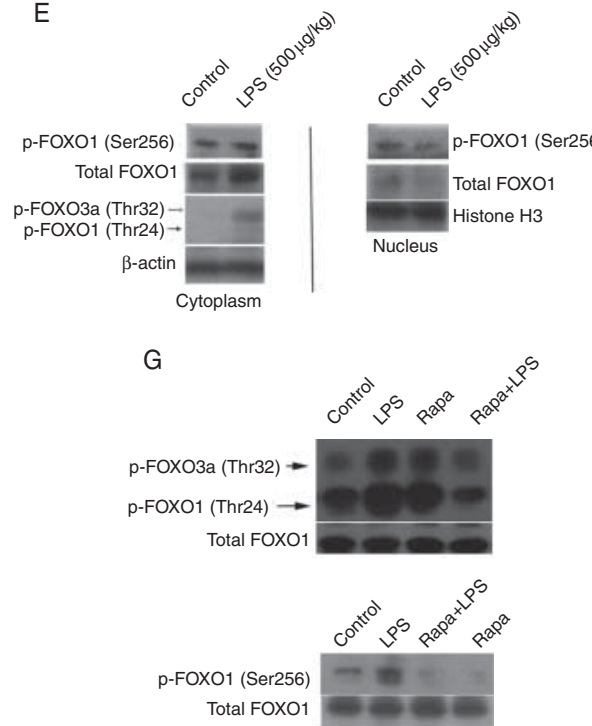
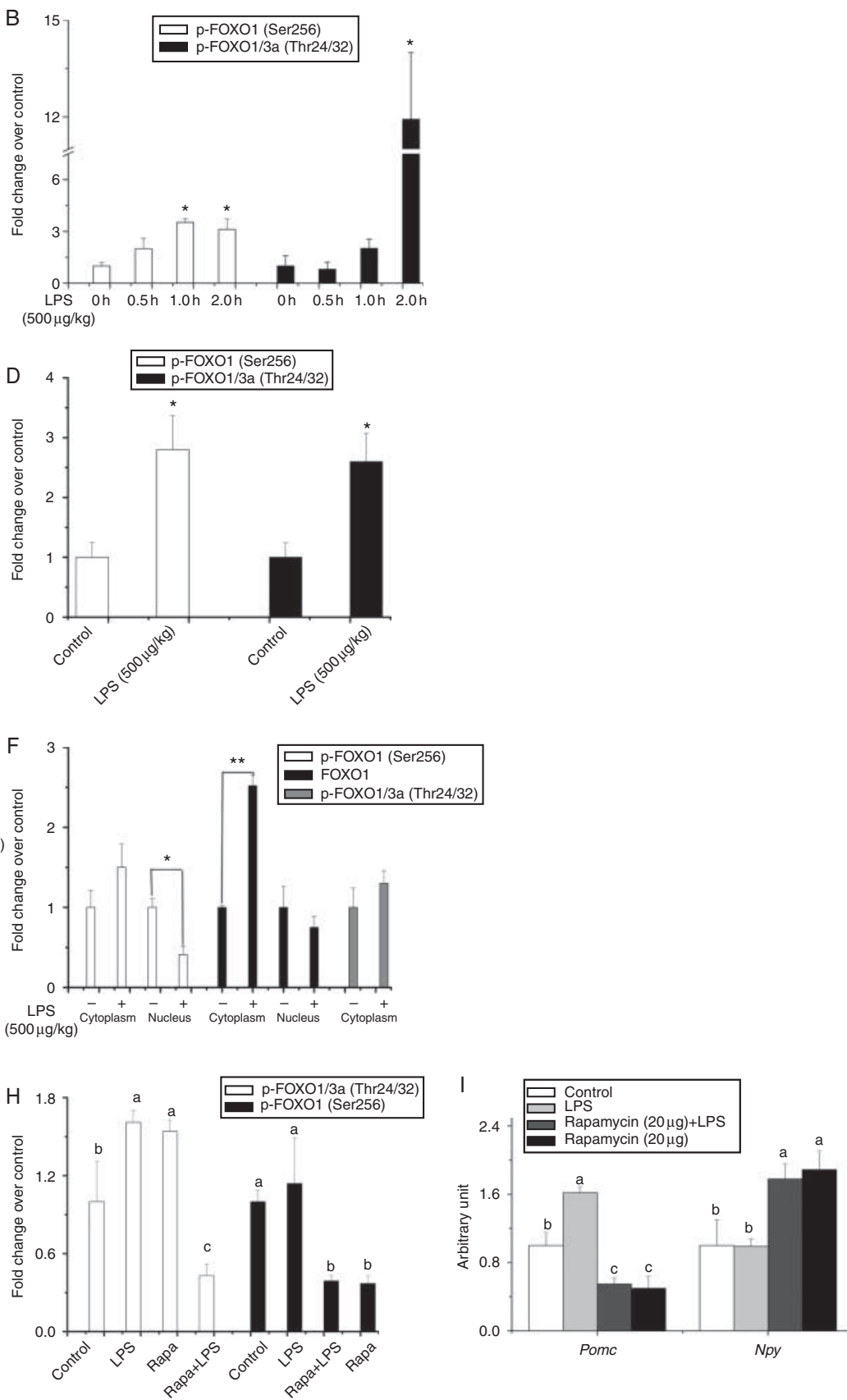

\section{Figure 4}

Effects of the mTOR on FOXO pathway in LPS-induced anorexia. Fasted mice were i.p. administered LPS ( $500 \mu \mathrm{g} / \mathrm{kg} \mathrm{BW})$. The phosphorylation of hypothalamic FOXO1 at Ser256 and FOXO1/3a at Thr24/32 (A and B) was determined at various time points after LPS treatment. Fasted mice were i.p. administered LPS (500 $\mu \mathrm{g} / \mathrm{kg}$ BW). Two hours later, the mice were killed by decapitation and the hypothalami were removed quickly. The phosphorylation of hypothalamic FOXO1 at Ser256 and FOXO1/3a at Thr24/32 ( $C$ and $D$ ) and the nuclear and cytoplasmic levels of these proteins were also determined $2 \mathrm{~h}$ after LPS $(500 \mu \mathrm{g} / \mathrm{kg})$ administration ( $\mathrm{E}$ and $\mathrm{F})$. Fasted mice were i.c.v. administered rapamycin (Rapa) $(20 \mu \mathrm{g} / 2 \mu \mathrm{l})$ or an equal volume of vehicle. One hour later, half of the mice were i.p. administered LPS (LPS and Rapa + LPS respectively). All measurements were determined $2 \mathrm{~h}$ after LPS treatment. The levels of hypothalamic phosphoFOXO1/3a Thr24/32 and phospho-FOXO1 (Ser256) (G and H). Two-way ANOVA showed a significant interaction between LPS and rapamycin treatment $(P<0.05)$. The mRNA levels of the appetite genes Pomc and Npy (I). Two-way ANOVA showed a significant interaction between LPS and rapamycin treatment $(P<0.05)$. The values are the means \pm s.E.M. $(n=6$ mice each group). Means without a common letter differ significantly $(* P<0.05$ and $* * P<0.01)$.

Published by Bioscientifica Ltd. 
no significant differences compared with treatment with LPS only $\left(P_{\text {Rapa } \times \text { LPS }}>0.05\right)$. Inhibition of mTOR did not induce a statistically significant change in the level of NFKB p65 phosphorylation at Ser536; however, this effect tended to be downregulated ( $P_{\text {Rapa }}=0.086$, Fig. 3D).

\section{Effects of LPS and mTOR inhibition on the phosphorylation of FOXO1 at Ser256 and Thr24 and FOXO3A at Thr32}

To explore the effect of LPS administration on FOXO1, we determined the FOXO1 activity by examining the phosphorylation level of FOXO1 at Ser256 and Thr24 and the phosphorylation of FOXO3a at Thr32. The phosphorylation levels of FOXO1 at Ser256 and Thr24 and FOXO3a at Thr32 were measured in mice that were killed at various time points $(0.5,1.0$, or $2.0 \mathrm{~h})$ after LPS (500 $\mu \mathrm{g} / \mathrm{kg} \mathrm{BW})$ administration. The results revealed that the phosphorylation levels of hypothalamic FOXO1 were enhanced after LPS administration $(P<0.05$, Fig. $4 \mathrm{~A}$ and $\mathrm{B})$. The phosphorylation levels of these proteins were then measured $2 \mathrm{~h}$ after LPS administration $(500 \mu \mathrm{g} / \mathrm{kg} \mathrm{BW})$. As shown in Fig. $4 \mathrm{C}$ and D, the phosphorylation levels of both FOXO1 and FOXO3a significantly increased $(P<0.05)$ after LPS treatment, increasing by 2.8- and 1.9-fold respectively. After i.p. injection of LPS, the phosphorylation of cytoplasmic FOXO1 at Ser256 and of FOXO1/3a at Thr24/Thr32 showed no statistically significant changes $(P>0.05$, Fig. $4 \mathrm{E}$ and $\mathrm{F})$; however, the total protein level of FOXO1 was increased in the cytoplasm $(P<0.05$, Fig. 4E and F) and decreased in the nucleus.

The phosphorylation level of FOXO1 at Ser256 and FOXO1/3a at Thr24/Thr32 induced by LPS was decreased significantly after mTOR inhibition compared with LPS treatment alone $\left(P_{\text {Rapa } \times \text { LPS }}<0.05\right.$, Fig. $4 \mathrm{G}$ and $\left.\mathrm{H}\right)$. When mTOR was blocked, the expression of the Pomc gene, which is induced by LPS, significantly decreased compared with LPS treatment alone; in contrast, there was an $~ 1.8$-fold increase in the expression of NPY when mTOR was inhibited, compared with the LPS treatment alone $\left(P_{\text {Rapa } \times \text { LPS }}<0.05\right.$, Fig. $\left.4 \mathrm{I}\right)$.

\section{Discussion}

The role of mTOR signaling in the regulation of food intake and the response to nutrient availability has been widely studied (Cota et al. 2006, Wullschleger et al. 2006). In this study, we report that the mTOR signaling pathway is involved in LPS-induced anorexia. We demonstrated that LPS administration stimulated the mTOR signaling pathway and the central blockade of the mTOR pathway

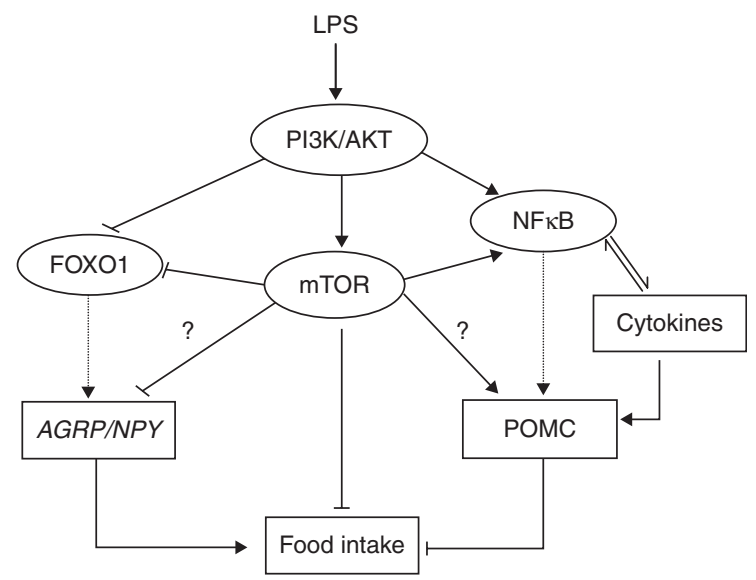

Figure 5

Proposed model of hypothalamic mTOR actions on LPS-induced anorexia in mice. LPS administration activated PI3K/AKT pathway and then stimulated mTOR and NFKB signaling, increasing the expression of cytokines and POMC. In contrary, activated mTOR inhibits the activity of FOXO1 and decreases the expression of the orexigenic appetite genes AGRP and NPY. The pathways collaborated with each other and resulted in lower food intake $(\rightarrow$, stimulatory; $\dashv$, inhibitory; $\rightarrow$, might be stimulatory; ?, need to be further studied; LPS, lipopolysaccharide; PI3K/AKT, phosphatidyl inositol 3-kinase; FoxO1, forkhead box O1; mTOR, mammalian target of rapamycin; $\mathrm{NF} \kappa \mathrm{B}$, nuclear factor kappa B; AgRP, agouti-related peptide; NPY, neuropeptide Y; POMC, pro-opiomelanocortin).

attenuated the LPS-induced anorexia. The result suggests that the $\mathrm{NF \kappa B}$ and FoxO1 pathways may be associated with the regulation of mTOR in LPS-induced anorexia. The proposed model of mTOR actions on LPS-induced anorexia in mice is shown in Fig. 5.

\section{NFKB activation in the hypothalamus is involved in LPS-induced anorexia}

In this study, a single i.p. injection of LPS $500 \mu \mathrm{g} / \mathrm{kg} \mathrm{BW}$ was used to induce peripheral inflammation (Bassi et al. 2012, Iwasa et al. 2014). LPS administration induced anorexia, which is in line with previous studies (Gautron et al. 2005, Ogimoto et al. 2006). LPS administration stimulates the release of pro-inflammatory cytokines such as IL1, TNF $\alpha$, IL6, and so on (O'Reilly et al. 1988, Plata-Salaman 1999, Wong \& Pinkney 2004, Bennani-Baiti $\&$ Walsh 2011). These cytokines may be associated with the induction of anorexia; however, hypothalamic inflammatory signals, rather than peripheral, have been identified as the major causes of LPS-induced anorexia (Laye et al. 2000, Plata-Salaman 2000, Wisse et al. 2007). In line with previous studies, the mRNA levels of cytokines such as $I L 1 \alpha, I L 1 \beta, T N F \alpha$, and IL6 were significantly increased in the hypothalamus after LPS administration.

Published by Bioscientifica Ltd 
Although the critical role of the hypothalamic inflammatory signal in LPS-induced anorexia has been recognized, it is unclear how the central melanocortin system is regulated accordingly. A recent study has revealed that $\mathrm{NF} \kappa \mathrm{B}$ directly bound the POMC gene to promote transcription in response to LPS stimulation (Jang et al. 2010), and meanwhile, the transcriptional level of NFкB was upregulated by LPS treatment in the hypothalamus. Nuclear translocation of NFкB has been shown to be insufficient for the maximal activation of NFאB (Chen \& Greene 2004). It has also been revealed that phosphorylation of the NFאB p65 subunit contributes to the transcriptional activation of NFאB (Sakurai et al. 1999). In this study, we found that i.p. administration of LPS activated hypothalamic NFKB by increasing the phosphorylation of the p65 subunit, the higher level of NFкB in the nucleus, and the upregulated expression of $P O M C$ may imply that the translocation of $\mathrm{NF} \kappa \mathrm{B}$ from cytoplasm into nucleus is related to the transcription of target genes such as POMC during LPS stimuli. These findings (Campo et al. 2010, Jang et al. 2010, Deshpande et al. 2011) collectively imply that $\mathrm{NF} \kappa \mathrm{B}$ activation in the hypothalamus plays a critical role in LPS-induced anorexia.

\section{The mTOR pathway plays a critical role in LPS-induced anorexia}

Hypothalamic mTOR is an important molecule in energy homeostasis. Activation of the mTOR cascade has been linked with decreased food intake, and mTOR blockade attenuates anorexia and weight loss induced by insulin and leptin in the CNS (Cota et al. 2006, Morton et al. 2006). We observed that mTOR signaling was enhanced through the phosphorylation of $\mathrm{mTOR}^{\mathrm{Ser} 2448}$ and $\mathrm{p} 70 \mathrm{~S} 6 \mathrm{~K}^{\mathrm{Thr} 389}$ in the hypothalamus during the inflammatory process stimulated by LPS, which implies that the mTOR pathway may be associated with the suppressed food consumption induced by LPS. Therefore, we proposed that inhibition of hypothalamic mTOR could block the anorexigenic and weightreducing effects of LPS. The suppressed food intake by LPS was partly restored by mTOR pathway blockade, suggesting that the mTOR signaling pathway plays an important role in LPS-induced anorexia.

\section{Crosstalk of the mTOR and NFKB pathways in LPS-induced anorexia}

Peripherally, mTOR signaling is involved in the regulation of the cytokine-induced inflammatory response, and the inhibition of mTOR activation by rapamycin has been shown to inhibit IKK $\beta$-mediated tumorigenesis (Lee et al. 2007). It has also been reported that inhibition of mTOR decreases the production of proinflammatory cytokines, inhibits the phosphorylation of the NFאB p65 subunit, and attenuates acute lung injury after intratracheal LPS administration (Lorne et al. 2009). A previous report has shown that inhibition of $\mathrm{NF \kappa B}$ attenuated the reductions in body weight and food intake induced by tumors (Kawamura et al. 1999). However, the relationship between mTOR and NFкB in the hypothalamus remains unclear. In this experiment, the decreased phosphorylation level of NFкB p65 subunit by rapamycin treatment indicated that mTOR pathway inhibition may attenuate the inflammatory response induced by LPS in hypothalami. Furthermore, we observed that mTOR pathway inhibition attenuated LPS-stimulated transcriptional expression of Tnf $\alpha, I l 1 \alpha$, and Il1 $\beta\left(P_{\text {Rapa }}=0.05\right)$. These results are in accordance with Schmitz et al. (2008), who showed that serum TNF $\alpha$ was suppressed by rapamycin treatment in LPS challenged mice, whereas the level of IL6 essentially remained unchanged. However, in other cell/tissue types, such as monocytes, rapamycin exposure did reduce the LPS-induced IL6 release (Schaeffer et al. 2011), suggesting that the discrepancies among the studies investigating IL6 production in response to $\mathrm{mTOR}$ inhibition are dependent on the cell/tissue type and the environmental conditions. In line with previous observations, rapamycin treatment prevented an increase in IL1 $\alpha$ and tended to suppress mRNA expression of Il1 $\beta\left(P_{\text {Rapa }}=0.05\right)$ in response to LPS treatment, indicating that mTOR pathway inhibition attenuated LPS-induced cytokine expression in the hypothalamus. Harris et al. (2011) demonstrated that rapamycin inhibited IL1 $\beta$ secretion by bone marrow-derived cells treated with LPS. The result suggests that, in the hypothalami, the inhibition of mTOR pathway partially prevented the activation of $\mathrm{NF \kappa B}$ and, in turn, the production of proinflammatory cytokines, leading to the attenuation of anorexia induced by LPS.

\section{Effects of the mTOR on FOXO pathway in LPS-induced anorexia}

The FOXO transcription factors FOXO1, FOXO3a, and FOXO4 are the targets of PI3K signaling, which regulates their activity via phosphorylation (Tang et al. 1999). FOXO1 has been shown to be related to the regulation of food intake (Kim et al. 2006). Moreover, it is interesting that FOXO1 has also been associated with the production of certain cytokines, and knockdown of FOXO1 attenuates the hyper-inflammatory phenotype in the peripheral system

Published by Bioscientifica Ltd. 
(Crossland et al. 2008, Su et al. 2009, Brown et al. 2011). As downstream targets of PI3K, the interaction between FOXO and $\mathrm{mTOR}$ is complicated, and several reports have suggested that FOXO negatively regulates mTOR signaling under different physiological conditions (Gilley et al. 2003, Jia et al. 2004). In this study, the result indicated that the FOXO1 pathway in the hypothalamus is influenced by LPS treatment. It is interesting that our results also showed that mTOR inhibition by rapamycin alleviated the LPS-induced phosphorylation of FOXO1 at Thr24 (pThr24-FOXO1) and mTOR alone blocked the decrease in the phosphorylation level of FOXO1 (Ser256). These findings indicated that rapamycin could decrease the LPS-induced phosphorylation of FOXO1, partly through the inhibition of LPS-induced mTOR signaling, resulting in the reduced phosphorylation level of FOXO1/3a (Thr24/32), as well as through the direct suppression of FOXO1 Ser256 phosphorylation by mTOR; these findings were similar to the observed roles of rapamycin derivatives (Zeng et al. 2007). As FOXO1 has three phosphorylation sites (Thr24, Ser256, and Ser319), the influence of the different phosphorylation levels at Thr24 and Ser256 on the role of FOXO1 in mTOR-regulated appetite control needs to be investigated further.

The proposed model of mTOR actions on LPS-induced anorexia in mice is shown in Fig. 5. LPS administration activated PI3K/AKT pathway and then stimulated mTOR and $\mathrm{NF \kappa B}$ signaling, increasing the expression of cytokines and POMC. In contrary, activated mTOR inhibits the activity of FOXO1 and decreases the expression of the orexigenic appetite genes AGRP and $N P Y$. The pathways collaborated with each other and resulted in lower food intake.

In conclusion, blocking the mTOR pathway significantly attenuated LPS-induced anorexia. Thus, this result suggests an attractive option to alleviate the development of LPS-induced anorexia.

\section{Declaration of interest}

The authors declare that there is no conflict of interest that could be perceived as prejudicing the impartiality of the research reported.

\section{Funding}

This work was supported by grants from the Natural Science Foundation of China (grant numbers 31072045 and 31272467).

\section{Acknowledgements}

The authors acknowledge the excellent technical assistance provided by Xianyao Li and Jingpeng Zhao.

\section{References}

Accili D \& Arden KC 2004 FoxOs at the crossroads of cellular metabolism, differentiation, and transformation. Cell 117 421-426. (doi:10.1016/ S0092-8674(04)00452-0)

Aoki M, Jiang H \& Vogt PK 2004 Proteasomal degradation of the FoxO1 transcriptional regulator in cells transformed by the P3k and Akt oncoproteins. PNAS 101 13613-13617. (doi:10.1073/pnas. 0405454101)

Bassi GS, Kanashiro A, Santin FM, de Souza GE, Nobre MJ \& Coimbra NC 2012 Lipopolysaccharide-induced sickness behaviour evaluated in different models of anxiety and innate fear in rats. Basic \& Clinical Pharmacology \& Toxicology 110 359-369. (doi:10.1111/j.1742-7843. 2011.00824.x)

Bennani-Baiti N \& Walsh D 2011 Animal models of the cancer anorexiacachexia syndrome. Supportive Care in Cancer 19 1451-1463. (doi:10.1007/s00520-010-0972-0)

Brown J, Wang H, Suttles J, Graves DT \& Martin M 2011 Mammalian target of rapamycin complex 2 (mTORC2) negatively regulates Toll-like receptor 4-mediated inflammatory response via FoxO1. Journal of Biological Chemistry 286 44295-44305. (doi:10.1074/jbc.M111.258053)

Campo GM, Avenoso A, Campo S, D'Ascola A, Nastasi G \& Calatroni A 2010 Molecular size hyaluronan differently modulates Toll-like receptor-4 in LPS-induced inflammation in mouse chondrocytes. Biochimie 92 204. (doi:10.1016/j.biochi.2009.10.006)

Chen LF \& Greene WC 2004 Shaping the nuclear action of NF- $\kappa$ B. Nature Reviews. Molecular Cell Biology 5 392-401. (doi:10.1038/nrm1368)

Cota D, Proulx K, Smith KA, Kozma SC, Thomas G, Woods SC \& Seeley RJ 2006 Hypothalamic mTOR signaling regulates food intake. Science $\mathbf{3 1 2}$ 927-930. (doi:10.1126/science.1124147)

Crossland H, Constantin-Teodosiu D, Gardiner SM, Constantin D \& Greenhaff PL 2008 A potential role for Akt/FOXO signaling in both protein loss and the impairment of muscle carbohydrate oxidation during sepsis in rodent skeletal muscle. Journal of Physiology $\mathbf{5 8 6}$ 5589-5600. (doi:10.1113/jphysiol.2008.160150)

Deshpande R, Khalili H, Pergolizzi RG, Michael SD \& Chang MDY 2011 Estradiol down-regulates LPS-induced cytokine production and NFkB activation in murine macrophages. American Journal of Reproductive Immunology 38 46-54. (doi:10.1111/j.1600-0897.1997.tb00275.x)

Finck BN, Kelley KW, Dantzer R \& Johnson RW 1998 In vivo and in vitro evidence for the involvement of tumor necrosis factor-alpha in the induction of leptin by lipopolysaccharide. Endocrinology 139 2278-2283. (doi:10.1210/endo.139.5.6012)

Gautron L, Mingam R, Moranis A, Combe C \& Laye S 2005 Influence of feeding status on neuronal activity in the hypothalamus during lipopolysaccharide-induced anorexia in rats. Neuroscience 134 933-946. (doi:10.1016/j.neuroscience.2005.03.063)

Gilley J, Coffer PJ \& Ham J 2003 FOXO transcription factors directly activate bim gene expression and promote apoptosis in sympathetic neurons. Journal of Cell Biology 162 613-622. (doi:10.1083/jcb.200303026)

Grunfeld C, Wilking H, Neese R, Gavin LA, Moser AH, Gulli R, Serio MK \& Feingold KR 1989 Persistence of the hypertriglyceridemic effect of tumor necrosis factor despite development of tachyphylaxis to its anorectic/cachectic effects in rats. Cancer Research 49 2554-2560.

Harris J, Hartman M, Roche C, Zeng SG, O'Shea A, Sharp FA, Lambe EM, Creagh EM, Golenbock DT, Tschopp J et al. 2011 Autophagy controls IL-1 $\beta$ secretion by targeting pro-IL-1 $\beta$ for degradation. Journal of Biological Chemistry 286 9587-9597. (doi:10.1074/jbc.M110.202911)

Hayden MS \& Ghosh S 2008 Shared principles in NF-кB signaling. Cell 132 344-362. (doi:10.1016/j.cell.2008.01.020)

Iwasa T, Matsuzaki T, Kinouchi R, Gereltsetseg G, Murakami M, Munkhzaya M, Altankhuu T, Kuwahara A, Yasui T \& Irahara M 2014 Changes in central and peripheral inflammatory responses to lipopolysaccharide in ovariectomized female rats. Cytokine 65 65-73. (doi:10.1016/j.cyto.2013.10.004) 
Jang PG, Namkoong C, Kang GM, Hur MW, Kim SW, Kim GH, Kang Y, Jeon MJ, Kim EH, Lee MS et al. 2010 NF- $\kappa B$ activation in hypothalamic pro-opiomelanocortin neurons is essential in illness-and leptininduced anorexia. Journal of Biological Chemistry 285 9706-9715. (doi:10.1074/jbc.M109.070706)

Jia K, Chen D \& Riddle DL 2004 The TOR pathway interacts with the insulin signaling pathway to regulate C. elegans larval development, metabolism and life span. Development 131 3897-3906. (doi:10.1242/ dev.01255)

Johnson RW 1997 Inhibition of growth by pro-inflammatory cytokines: an integrated view. Journal of Animal Science 75 1244-1255.

Kamei Y, Miura S, Suzuki M, Kai Y, Mizukami J, Taniguchi T, Mochida K, Hata T, Matsuda J, Aburatani H et al. 2004 Skeletal muscle FOXO1 (FKHR) transgenic mice have less skeletal muscle mass, down-regulated type I (slow twitch/red muscle) fiber genes, and impaired glycemic control. Journal of Biological Chemistry 279 41114-41123. (doi:10.1074/ jbc.M400674200)

Kawamura I, Morishita R, Tomita N, Lacey E, Aketa M, Tsujimoto S, Manda T, Tomoi M, Kida I, Higaki J et al. 1999 Intratumoral injection of oligonucleotides to the NFKB binding site inhibits cachexia in a mouse tumor model. Gene Therapy 6 91-97. (doi:10.1038/sj.gt. 3300819)

Kim MS, Park JY, Namkoong C, Jang PG, Ryu JW, Song HS, Yun JY, Namgoong IS, Ha J \& Park IS 2004 Anti-obesity effects of $\alpha$-lipoic acid mediated by suppression of hypothalamic AMP-activated protein kinase. Nature Medicine 10 727-733. (doi:10.1038/nm1061)

Kim MS, Pak YK, Jang PG, Namkoong C, Choi YS, Won JC, Kim KS, Kim SW, Kim HS, Park JY et al. 2006 Role of hypothalamic Foxo1 in the regulation of food intake and energy homeostasis. Nature Neuroscience 9 901-906. (doi:10.1038/nn1731)

Kim JJ, Li P, Huntley J, Chang JP, Arden KC \& Olefsky JM 2009 FoxO1 haploinsufficiency protects against high-fat diet-induced insulin resistance with enhanced peroxisome proliferator-activated receptor gamma activation in adipose tissue. Diabetes 58 1275-1282. (doi:10.2337/db08-1001)

Kim HJ, Sung MK \& Kim JS 2011 Anti-inflammatory effects of glyceollins derived from soybean by elicitation with Aspergillus sojae. Inflammation Research 60 909-917. (doi:10.1007/s00011-011-0351-4)

Kitamura T, Feng Y, Kitamura YI, Chua SC Jr, Xu AW, Barsh GS, Rossetti L \& Accili D 2006 Forkhead protein FoxO1 mediates Agrp-dependent effects of leptin on food intake. Nature Medicine 12 534-540. (doi:10.1038/ nm1392)

Laye S, Gheusi G, Cremona S, Combe C, Kelley K, Dantzer R \& Parnet P 2000 Endogenous brain IL-1 mediates LPS-induced anorexia and hypothalamic cytokine expression. American Journal of Physiology. Regulatory, Integrative and Comparative Physiology 279 R93-R98.

Lee DF, Kuo HP, Chen CT, Hsu JM, Chou CK, Wei Y, Sun HL, Li LY, Ping B \& Huang WC 2007 IKK $\beta$ suppression of TSC1 links inflammation and tumor angiogenesis via the mTOR pathway. Cell 130 440-455. (doi:10.1016/j.cell.2007.05.058)

Li N \& Karin M 1999 Is NF-kB the sensor of oxidative stress? FASEB Journal 13 1137-1143.

Livak KJ \& Schmittgen TD 2001 Analysis of relative gene expression data using real-time quantitative PCR and the $2^{(-\Delta \Delta C(\mathrm{~T}))}$ method. Methods 25 402-408. (doi:10.1006/meth.2001.1262)

Lorne E, Zhao X, Zmijewski JW, Liu G, Park YJ, Tsuruta Y \& Abraham E 2009 Participation of mammalian target of rapamycin complex 1 in Toll-like receptor 2- and 4-induced neutrophil activation and acute lung injury. American Journal of Respiratory Cell and Molecular Biology $\mathbf{4 1}$ 237. (doi:10.1165/rcmb.2008-02900C)

Matsuzaki H, Daitoku H, Hatta M, Tanaka K \& Fukamizu A 2003 Insulininduced phosphorylation of FKHR (Foxo1) targets to proteasomal degradation. PNAS 100 11285-11290. (doi:10.1073/pnas.1934283100)

Monick MM, Carter AB, Robeff PK, Flaherty DM, Peterson MW \& Hunninghake GW 2001 Lipopolysaccharide activates Akt in human alveolar macrophages resulting in nuclear accumulation and transcriptional activity of $\beta$-catenin. Journal of Immunology $1664713-$ 4720. (doi:10.4049/jimmunol.166.7.4713)

Morton GJ, Cummings DE, Baskin DG, Barsh GS \& Schwartz MW 2006 Central nervous system control of food intake and body weight. Nature 443 289-295. (doi:10.1038/nature05026)

Nakae J, Biggs WH, Kitamura T, Cavenee WK, Wright CV, Arden KC \& Accili D 2002 Regulation of insulin action and pancreatic $\beta$-cell function by mutated alleles of the gene encoding forkhead transcription factor Foxo1. Nature Genetics 32 245-253. (doi:10.1038/ng890)

Niswender KD, Morton GJ, Stearns WH, Rhodes CJ, Myers MG \& SchwartzMW 2001 Intracellular signalling: key enzyme in leptin-induced anorexia. Nature 413 794-795. (doi:10.1038/35101657)

Niswender KD, Morrison CD, Clegg DJ, Olson R, Baskin DG, Myers MG, Seeley RJ \& Schwartz MW 2003 Insulin activation of phosphatidylinositol 3-kinase in the hypothalamic arcuate nucleus a key mediator of insulin-induced anorexia. Diabetes 52 227-231. (doi:10.2337/diabetes. 52.2.227)

Ogimoto K, Harris MK \& Wisse BE 2006 MyD88 is a key mediator of anorexia, but not weight loss, induced by lipopolysaccharide and interleukin-1ß. Endocrinology 147 4445-4453. (doi:10.1210/ en.2006-0465)

O'Reilly B, Vander AJ \& Kluger MJ 1988 Effects of chronic infusion of lipopolysaccharide on food intake and body temperature of the rat. Physiology \& Behavior 42 287-291. (doi:10.1016/0031-9384(88)90084-4)

Plata-Salaman CR 1999 Brain mechanisms in cytokine-induced anorexia. Psychoneuroendocrinology 24 25-41. (doi:10.1016/S03064530(98)00045-6)

Plata-Salaman CR 2000 Central nervous system mechanisms contributing to the cachexia-anorexia syndrome. Nutrition 16 1009-1012. (doi:10.1016/S0899-9007(00)00413-5)

Ropelle ER, Fernandes MF, Flores MB, Ueno M, Rocco S, Marin R, Cintra DE, Velloso LA, Franchini KG, Saad MJ et al. 2008a Central exercise action increases the AMPK and mTOR response to leptin. PLoS ONE 3 e3856. (doi:10.1371/journal.pone.0003856)

Ropelle ER, Pauli JR, Fernandes MF, Rocco SA, Marin RM, Morari J, Souza KK, Dias MM, Gomes-Marcondes MC, Gontijo JA et al. 2008b A central role for neuronal AMP-activated protein kinase (AMPK) and mammalian target of rapamycin (mTOR) in high-protein diet-induced weight loss. Diabetes 57 594-605. (doi:10.2337/db07-0573)

Sakurai H, Chiba H, Miyoshi H, Sugita T \& Toriumi W 1999 IкB kinases phosphorylate NF- $\mathrm{KB}$ p65 subunit on serine 536 in the transactivation domain. Journal of Biological Chemistry 274 30353-30356. (doi:10.1074/ jbc.274.43.30353)

Schaeffer V, Arbabi S, Garcia IA, Knoll ML, Cuschieri J, Bulger EM \& Maier RV 2011 Role of the mTOR pathway in LPS-activated monocytes: influence of hypertonic saline. Journal of Surgical Research 171 769-776. (doi:10.1016/j.jss.2010.05.035)

Schmitz F, Heit A, Dreher S, Eisenächer K, Mages J, Haas T, Krug A, Janssen KP, Kirschning CJ \& Wagner H 2008 Mammalian target of rapamycin (mTOR) orchestrates the defense program of innate immune cells. European Journal of Immunology 38 2981-2992. (doi:10.1002/eji.200838761)

Segreti J, Gheusi G, Dantzer R, Kelley KW \& Johnson RW 1997 Defect in interleukin-1 $\beta$ secretion prevents sickness behavior in $\mathrm{C} 3 \mathrm{H} / \mathrm{HeJ}$ mice. Physiology \& Behavior 61 873-878. (doi:10.1016/S0031-9384(96)00611-7)

Sergeyev V, Broberger C \& Hokfelt T 2001 Effect of LPS administration on the expression of POMC, NPY, galanin, CART and MCH mRNAs in the rat hypothalamus. Molecular Brain Research 90 93-100. (doi:10.1016/ S0169-328X(01)00088-2)

Socher SH, Friedman A \& Martinez D 1988 Recombinant human tumor necrosis factor induces acute reductions in food intake and body weight in mice. Journal of Experimental Medicine 167 1957-1962. (doi:10.1084/ jem.167.6.1957)

Su D, Coudriet GM, Hyun Kim D, Lu Y, Perdomo G, Qu S, Slusher S, Tse HM, Piganelli J, Giannoukakis N et al. 2009 FoxO1 links insulin resistance to

Published by Bioscientifica Ltd. 
proinflammatory cytokine IL-1 $\beta$ production in macrophages. Diabetes 58 2624-2633. (doi:10.2337/db09-0232)

Tang ED, Nunez G, Barr FG \& Guan KL 1999 Negative regulation of the forkhead transcription factor FKHR by Akt. Journal of Biological Chemistry 274 16741-16746. (doi:10.1074/jbc.274.24.16741)

Tracey KJ, Wei H, Manogue KR, Fong Y, Hesse DG, Nguyen HT, Kuo GC, Beutler B, Cotran RS \& Cerami A 1988 Cachectin/tumor necrosis factor induces cachexia, anemia, and inflammation. Journal of Experimental Medicine 167 1211-1227. (doi:10.1084/jem.167.3.1211)

Verhulst PJ, Janssen S, Tack J \& Depoortere I 2012 Role of the AMP-activated protein kinase (AMPK) signaling pathway in the orexigenic effects of endogenous ghrelin. Regulatory Peptides 173 27-35. (doi:10.1016/j.regpep.2011.09.001)
Wisse BE, Ogimoto K, Tang J, Harris MK, Raines EW \& Schwartz MW 2007 Evidence that lipopolysaccharide-induced anorexia depends upon central, rather than peripheral, inflammatory signals. Endocrinology 148 5230-5237. (doi:10.1210/en.2007-0394)

Wong S \& Pinkney J 2004 Role of cytokines in regulating feeding behaviour. Current Drug Targets 5 251-263. (doi:10.2174/ 1389450043490532)

Wullschleger S, Loewith R \& Hall MN 2006 TOR signaling in growth and metabolism. Cell 124 471-484. (doi:10.1016/i.cell.2006.01.016)

Zeng Z, Sarbassov DD, Samudio IJ, Yee KW, Munsell MF, Jackson CE, Giles FJ, Sabatini DM, Andreeff M \& Konopleva M 2007 Rapamycin derivatives reduce mTORC2 signaling and inhibit AKT activation in AML. Blood 109 3509-3512. (doi:10.1182/blood-2006-06-030833)

Received in final form 7 October 2014

Accepted 27 October 2014

Accepted Preprint published online 27 October 2014 http://joe.endocrinology-journals.org DOI: 10.1530/JOE-14-0523
() 2015 Society for Endocrinology Printed in Great Britain
Published by Bioscientifica Ltd. 